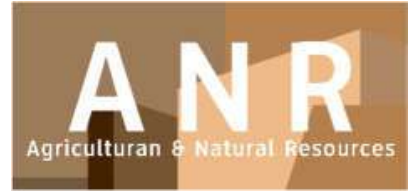

PAPER - OPEN ACCESS

\title{
Perubahan Penutupan Lahan Kota Bogor
}

\author{
Author : Ina Lidiawati, dkk \\ DOI $\quad: 10.32734 /$ anr.v2i1.572 \\ Electronic ISSN $\quad: 2654-7023$ \\ Print ISSN : :2654-7015
}

Volume 2 Issue 1 - 2019 TALENTA Conference Series: Agricultural and Natural Resources (ANR)

\section{(c) (i) $\ominus$}

This work is licensed under a Creative Commons Attribution-NoDerivatives 4.0 International License.

Published under licence by TALENTA Publisher, Universitas Sumatera Utara 


\title{
نं \\ ANR Conference Series 02 (2019)

talentabion

\section{Perubahan Penutupan Lahan Kota Bogor}

\author{
(Land Use Changes in Bogor City)
}

\author{
Ina Lidiawati ${ }^{a}$, Ratna Sari Hasibuan ${ }^{a}$ dan Retno Wijayanti ${ }^{b}$ \\ ${ }^{a}$ Universitas Nusa Bangsa, Bogor 16166, Indonesia \\ ${ }^{b}$ Kementerian Lingkungan Hidup dan Kehutanan, Jakarta, 13410, Indonesia
}

Email: inalidiawati@yahoo.co.id, ratna@unb.ac.id, retno13.wijayanti@gmail.com

\begin{abstract}
Abstrak
Pembangunan yang terjadi sangat pesat sehingga tutupan lahan di Kota Bogor berubah. Penelitian ini bertujuan untuk mengetahui tutupan lahan Kota Bogor yang berubah yaitu tahun 1996, 2006, 2016 dan faktor-faktor yang mempengaruhi tutupan lahan Kota Bogor yang berubah tersebut. Perubahan tutupan lahan Kota Bogor dianalisis menggunakan perangkat lunak Arc.GIS 10.2. Data yang digunakan sebagai bahan analisis adalah peta tutupan lahan Kota Bogor 1996, 2006 dan 2016 dari Kementerian Lingkungan Hidup dan Kehutanan (KLHK) dan peta Rupa Bumi Indonesia (RBI). Hasil dari penelitian ini adalah klasifikasi kelas tutupan lahan hutan tanaman kota Bogor, area terbuka, pelabuhan/bandara, pemukiman/lahan, pertanian kering, pertanian kering, semak, sawah, perkebunan, dan badan air. Pada tahun 1996 tutupan lahan didominasi oleh vegetasi, semak, dan semak-semak. Perubahan tutupan lahan yang paling masif terjadi pada kelas permukiman / tanah dengan luas 6.683 hektar pada tahun 2006 dan 7.532 ha pada tahun 2016. Diperkirakan bahwa luas lahan yang akan dibangun akan terus bertambah seiring dengan pertambahan populasi. Peningkatan populasi menyebabkan lebih banyak ruang untuk perumahan dan berbagai kegiatan, selain kondisi sosial ekonomi dan arah kebijakan pemerintah yang mempengaruhi tutupan lahan kota Bogor menjadi berubah.
\end{abstract}

Kata kunci: Tutupan Lahan, Klasifikasi Penutupan Lahan, Kota Bogor

\begin{abstract}
Development that occurred in the city of Bogor very rapidly causing land cover changes. This research purpose was to know the change of land cover of Bogor City in 1996, 2006, and 2016 and to know what factors influence the change of land cover. Changes in land cover in Bogor City were analyzed using Arc.GIS software 10.2. The data used as an analysis material were the land cover map of Bogor City 1996, 2006 and 2016 issued by the Ministry of Environment and Forestry and the map of Rupa Bumi Indonesia issued by the Geospatial Information Agency. This research result was the classification of a land cover class of Bogor city of plantation forest, open area, port/airport, settlement/land, dry farm, dry farm, shrub, rice field, plantation, and water body. In 1996 the land cover was dominated by vegetation, shrubs, and bushes. The most massive land cover change occurred in the class of settlements/land with an area of 6,683 hectares in 2006 and 7,532 ha in the year 2016. It is estimated that the area of land will be built will continue to grow as the population increases. The increase in population causes more space for housing and various activities, besides the socio-economic condition and the direction of government policy also affect the change of land cover in Bogor city.
\end{abstract}

Keywords: land cover, land cover classification, Bogor City

(C) 2019 The Authors. Published by TALENTA Publisher Universitas Sumatera Utara

Selection and peer-review under responsibility of Pertemuan Ilmiah Tahunan (PIT) dan Seminar Nasional Ke-4,

Komunitas Manajemen Hutan Indonesia (KOMHINDO)

p-ISSN: 2654-7015, e-ISSN: 2654-7023, DOI: 10.32734/anr.v2i1.572 


\section{Pendahuluan}

Kemajuan teknologi dan tingkat kebutuhan manusia yang meningkat mengakibatkan penggunaan lahan di Kota Bogor meningkat. Pertambahan penduduk yang pesat juga diiringi dengan pertambahan permintaan terhadap pemenuhan kebutuhan. Pembangunan merupakan salah satu upaya pemenuhan kebutuhan hidup masyarakat. Beberapa penelitian menunjukkan bahwa urbanisasi di wilayah perkotaan telah meningkat dengan sangat cepat. Menurut "[1] konversi lahan lahan hijau menjadi area terbangun di Jabodetabek sebesar $23 \%$ dalam jangka waktu 25 tahun". Menurut [2], "lahan merupakan tanah, iklim, relief, hidrologi, dan vegetasi dimana faktor- faktor tersebut mempengaruhi potensi penggunaannya, termasuk didalamnya adalah akibat-akibat kegiatan manusia, baik pada masa lalu maupun sekarang, seperti reklamasi daerah daerah pantai, penebangan hutan, dan akibat akibat merugikan seperti erosi". "Interaksi antara masyarakat dan lahan yang menyebabkan terjadinya perubahan terhadap penggunaan lahan memiliki potensi menimbulkan dampak negatif yang besar terhadap lingkungan. "Untuk itu adanya upaya pemantauan terhadap perubahan lahan agar dampak negatif akibat perubahan lahan dapat ditanggulangi dan upaya pengelolaan lingkungan ke depan bisa direncanakan dengan tetap mengacu kepada optimalisasi manfaat sumberdaya secara lestari”.

Pembangunan yang begitu besar menjadikan lahan-lahan kosong menjadi semikin sedikit. Lahan-lahan kosong yang ada di Kota Bogor menjadi semakin menurun untuk memenuhi kebutuhan sarana dan prasarana penduduk yang berakibat pada terbatasnya sumber daya lahan. Perubahan lahan hijau menjadi lahan terbangun akan menyebabkan terjadinya perubahan tutupan lahan. Penelitian ini bertujuan untuk mengetahui tutupan lahan Kota Bogor yang berubah yaitu tahun 1996, 2006, 2016 dan faktor-faktor yang mempengaruhi tutupan lahan Kota Bogor yang berubah tersebut.

\section{Metode Penelitian}

Penelitian ini dilaksanakan di Kota Bogor dari bulan Mei sampai Agustus 2017. Alat yang digunakan adalah perangkat lunak Arc.GIS 10.2,dan bahan yang digunakan adalah peta RBI skala 1:25.000, peta penutupan lahan Kota Bogor tahun 1996, 2006 dan 2016 dan data pertumbuhan penduduk.

Metode deskriptif yang digunakan dalam penelitian ini yaitu mendeskripsikan hasil analisis dari beberapa peta. Proses analisis awal terdiri dari beberapa tahapan yang dimulai dengan memotong peta RBI untuk mengambil bagian wilayah Kota Bogor, hal ini dilakukan untuk memperoleh informasi mengenai batas administrasi, jalan dan sungai. Selanjutnya hal yang sama dilakukan pada peta penutupan lahan yang diperoleh dari KLHK, peta ini merupakan peta hasil olahan citra satelit. Data-data tersebut kemudian dipilah dan dipotong untuk diambil wilayah Kota Bogor saja, dan selanjutnya dilakukan kembali tahap pemisahan berdasarkan tahun yang telah ditetapkan. Semua proses ini dibantu oleh perangkat lunak Arc.GIS 10.2 yang ada di KLHK. Peta-peta tersebut kemudian diolah dan dianalisa untuk memperoleh hasil sesuai dengan tujuan penelitian. Pada masing-masing peta dilakukan identifikasian area yang mewakili setiap penutupan lahan. Klasifikasi peta dilakukan sehingga terlihat perubahan tutupan lahannya.

\section{Hasil dan Pembahasan}

\subsection{Perubahan Tutupan Lahan Kota Bogor tahun 1996, 2006, 2016}

Berdasarkan penelitian, diketahui bahwa terdapat beberapa jenis klasifikasi penutupan lahan di Kota Bogor. Sesuai dengan Peraturan Direktur Jenderal Planologi Kehutanan Nomor P.1/VII-IPSDH/2015 tentang Pedoman Pemantauan Penutupan Lahan, yakni hutan tanaman, lahan terbuka, pelabuhan/bandara, permukiman/lahan terbangun, pertanian lahan kering, pertanian lahan kering campur semak, sawah, perkebunan,dan tubuh air [3] . Klasifikasi kelas penutupan lahan kota Bogor tahun 1996, 2006 dan 2016 dapat dilihat pada Tabel 1 dan Gambar 1. 
Tabel 1. Klasifikasi Kelas Penutupan Lahan Kota Bogor Tahun 1996, 2006 dan 2016

\begin{tabular}{|c|c|c|c|c|}
\hline No. & Jenis Penutupan Lahan & \multicolumn{3}{|c|}{ Luas (Ha) } \\
\hline & & Thn 1996 & Thn 2006 & Thn 2016 \\
\hline 1 & 2 & 3 & 4 & 5 \\
\hline 1 & Hutan Tanaman & 204 & 204 & 129 \\
\hline 2 & Lahan Terbuka & 397 & - & - \\
\hline 3 & Pelabuhan/Bandara & 6 & 6 & - \\
\hline 4 & Permukiman/Lahan Terbangun & 476 & 6.683 & 7.532 \\
\hline 5 & Pertanian Lahan Kering & 6.306 & 1.967 & 3.362 \\
\hline 6 & Pertanian Lahan Kering Campur Semak & 3.659 & 2.021 & 114 \\
\hline 7 & Sawah & 472 & 472 & 378 \\
\hline 8 & Tubuh Air & - & - & 4 \\
\hline 9 & Perkebunan & - & 167 & - \\
\hline & Jumlah & 11.520 & 11.520 & 11.520 \\
\hline
\end{tabular}

Untuk mendapatkan kelas penutupan lahan tahun 1996, Kementerian Lingkungan Hidup dan kehutanan melakukan analisis citra menggunakan citra satelit landsat 5 dengan resolusi $30 \times 30 \mathrm{~m}$, dan metode penafsiran yang digunakan pada saat itu adalah secara manual. Kondisi tutupan lahan Kota Bogor Tahun 1996 masih di dominasi oleh penutupan lahan yang bertutupan vegetasi, lahan kering yakni seluas 6.306 Ha. Hampir semua Kecamatan di Kota Bogor didominasi oleh tutupan lahan kelas pertanian lahan kering campur semak yakni seluas 3.659 Ha. Kelas penutupan lahan permukiman/lahan terbangun menempati urutan ketiga dengan luas sebesar 476 Ha. Diikuti oleh penutupan lahan kelas sawah sebesar $472 \mathrm{Ha}$, kelas lahan terbuka seluas $397 \mathrm{Ha}$, kelas hutan tanaman seluas $204 \mathrm{Ha}$ dan kelas pelabuhan/bandara seluas 6 Ha. Kondisi penutupan lahan ini menggambarkan bahwa pada tahun 1996 kebutuhan akan lahan untuk pembangunan terlihat masih sedikit. Hal ini sangat berdampak positif untuk kondisi lingkungan Kota Bogor, udara yang segar dan pemandangan yang asri masih bisa dinikmati pada saat itu.

Citra satelit digunakan untuk Penafsiran citra tahun 2006 sehingga mengalami perkembangan bila dibandingkan tahun 1996. Citra satelit landsat 7 yang digunkan untuk melakukan penafsiran yang dilengkapi dengan fasilitas penerima sistem posisi lokasi (Ground Positioning System/ GPS receiver). Tutupan lahan yang terbesar tahun 2006 adalah kelas tutupan lahan permukiman/lahan terbangun dengan luasan 6.683 Ha dari total luasan Kota Bogor. Penambahan luas penutupan lahan permukiman/lahan terbangun ini berasal dari kelas lahan terbuka, pertanian lahan kering dan pertanian lahan kering campur semak. Dengan adanya penambahan luas perubahan penutupan lahan, maka dipastikan ada luasan kelas penutupan lahan lain yang menjadi berkurang. Hal ini terjadi pada penutupan lahan kelas lahan terbuka yang semula teridentifikasi di Tahun 1996 seluas 397 Ha, menjadi terbagi habis pada Tahun 2006 ini seluas 167 Ha menjadi perkebunan dan 230 Ha menjadi permukiman/lahan terbangun. Begitu juga dengan penutupan lahan kelas pertanian lahan kering yang berkurang seluas 5.733 Ha menjadi permukiman/lahan terbangun. Penutupan lahan kelas pertanian lahan kering campur semak juga mengalami perubahan di Tahun 2006, perubahan tersebut seluas $244 \mathrm{Ha}$ menjadi permukiman/lahan terbangun dan seluas 1.394 Ha menjadi Pertanian lahan kering. Dengan bertambahnya jumlah penduduk maka luas kelas penutupan lahan permukiman/lahan terbangun akan semakin bertambah (Gambar 1). Pertambahan jumlah penduduk menyebabkan kebutuhan ruang yang lebih untuk tempat tinggal dan berbagai aktivitas. Kondisi perubahan penutupan lahan menjadi permukiman/lahan terbangun ini akan menimbulkan dampak negatif untuk kondisi lingkungan Kota Bogor. 


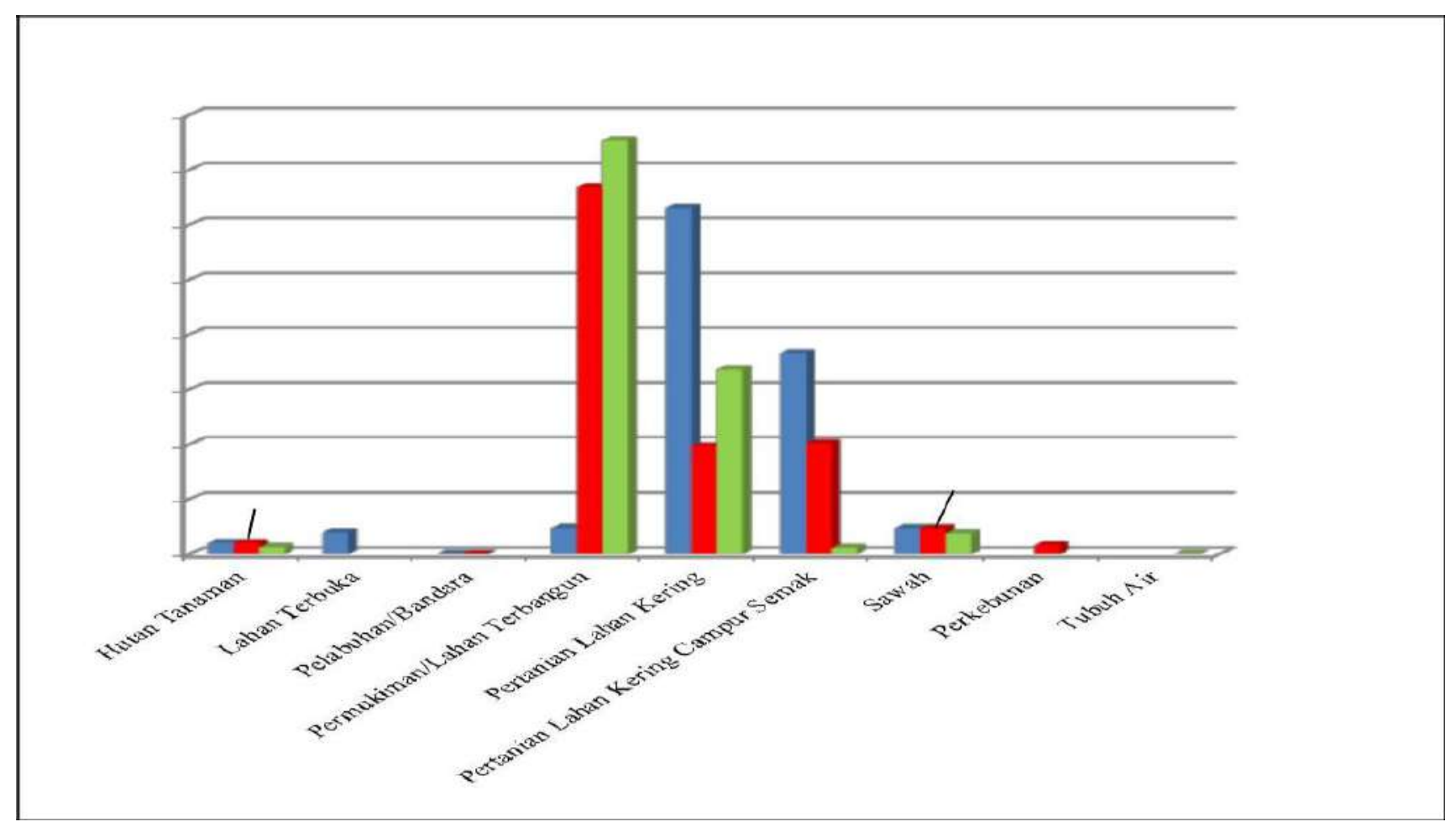

Gambar 1. Perubahan Penutupan Lahan Kota Bogor dari Tahun 1996, 2006 dan 2016

Dampak yang akan ditimbulkan dari perubahan penutupan lahan menjadi permukiman/lahan terbangun adalah pada kondisi suhu permukaan wilayah Kota Bogor, hal ini telah dibuktikan oleh [4] dalam hasil penelitiannya yang menyatakan bahwa pada Tahun 1997 hingga 2006 di Kota Bogor telah terjadi peningkatan suhu yaitu 24-28 $\mathrm{C}$. Perubahan tutupan lahan yang terjadi tidak hanya berpengaruh pada kondisi suhu tempat penutupan lahan itu sendiri tetapi juga berpengaruh pada kondisi suhu wilayah sekitarnya. Selain itu, perubahan penutupan lahan ke dalam kelas permukiman/lahan terbangun juga akan berdampak pada berubahnya sifa-sifat hidrologi yang akan menimbulkan dua kemungkinan yaitu banjir dan kekeringan. Pepohonan yang ada akan memperlambat air hujan yang jatuh. Air yang berada dalam badan tanah akan terserap oleh akar pohon dan alirannya akan diperlambat oleh tumbuhan bawah sehingga air hujan yang jatuh pada lahan yang tidak bervegetasi akan langsung mengenai badan tanah dan limpasannya akan tinggi yang dapat mengakibatkan erosi dan banjir. Sedangkan pada musim kemarau akan mengakibatkan kekeringan, karena kurangnya air tanah,seperti yang kemukakan oleh [5], "dengan adanya pembangunan sehingga terjadi perubahan tutupan lahan yang menyebabkan pohon-pohon semakin berkurang sehingga air hujan semakin cepat turun ke tanah."

Landsat 8 digunakan untuk penafsiran citra tahun 2016. Sensor Onboard Operational Land Imager (OLI) dan Thermal Infrared Sensor (TIRS) dimiliki oleh Satelit landsat 8 tersebut. Tidak jauh berbeda dari keadaan penutupan lahan Kota Bogor Tahun 2006, terdapat enam klasifikasi kelas penutupan lahan yang teridentifikasi berdasarkan peta penutupan lahan Kota Bogor Tahun 2016. Kelas penutupan lahan tersebut adalah hutan tanaman, permukiman/lahan terbangun, pertanian lahan kering, pertanian lahan kering campur semak, sawah dan tubuh air. Kelas permukiman/lahan terbangun masih mendominasi perubahan penutupan lahan Kota Bogor Tahun 2016. Hal ini terlihat pada besarnya angka luasan kelas permukiman/lahan terbangun yaitu sebesar 7.532 Ha. Penambahan luas perubahan penutupan lahan kelas permukiman/lahan terbangun diperoleh paling besar dari kelas pertanian lahan kering campur semak yakni seluas $940 \mathrm{Ha}$. Kelas pertanian lahan kering campur semak juga menyumbang angka sangat besar untuk perubahan yang terjadi pada kelas pertanian lahan kering sebesar $978 \mathrm{Ha}$. Lahan yang tadinya berupa semak belukar, sekarang lebih dimanfaatkan menjadi pertanian lahan kering. Perubahan penutupan lahan yang juga terjadi pada Tahun 2016 adalah kelas pelabuhan/bandara berubah seluas 4 Ha menjadi permukiman dan 2 Ha menjadi pertanian lahan kering, hal ini dapat terjadi karena pada penafsiran tahun 1996 dan 2006 masih berupa 
deliniasi pelabuhan/bandara. Sedangkan pada tahun 2016 telah terbangun permukiman pada deliniasi tersebut. Menurut [6] "faktor-faktor penyebab terjadinya perubahan penggunaan lahan : (1) terjadinya urbanisasi dikarenakan pembangunan di desa lambat, (2) pendapatan masyarakat semakin meningkat, sehingga kebutuhan perumahan semakin meningkat, (3) terjadinya transformasi di dalam struktur perekonomian yang pada gilirannya akan menggeser kegiatan pertanian/ lahan hijau khususnya di perkotaan , (4) terjadinya fragmentasi pemilikan lahan menjadi satuan satuan usaha dengan ukuran yang secara ekonomi tidak efisien". Secara lebih jelas peta perubahan penutupan lahan kota Bogor tahun 1996,2006 dan 2016 dapat dilihat pada Gambar 2 di bawah ini .

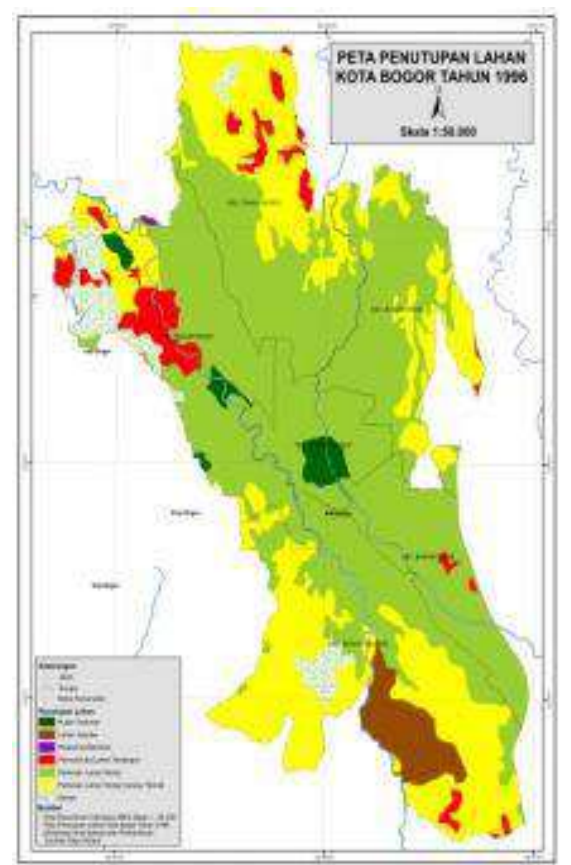

(a)

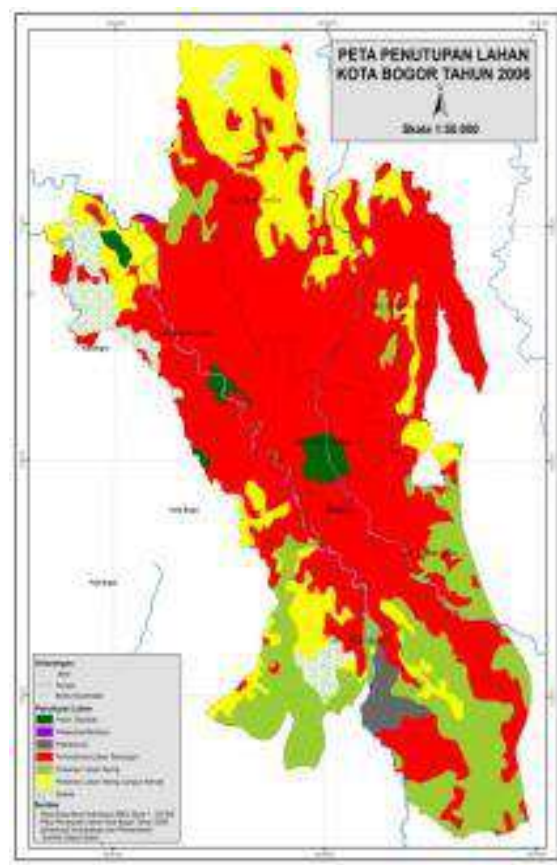

(b)

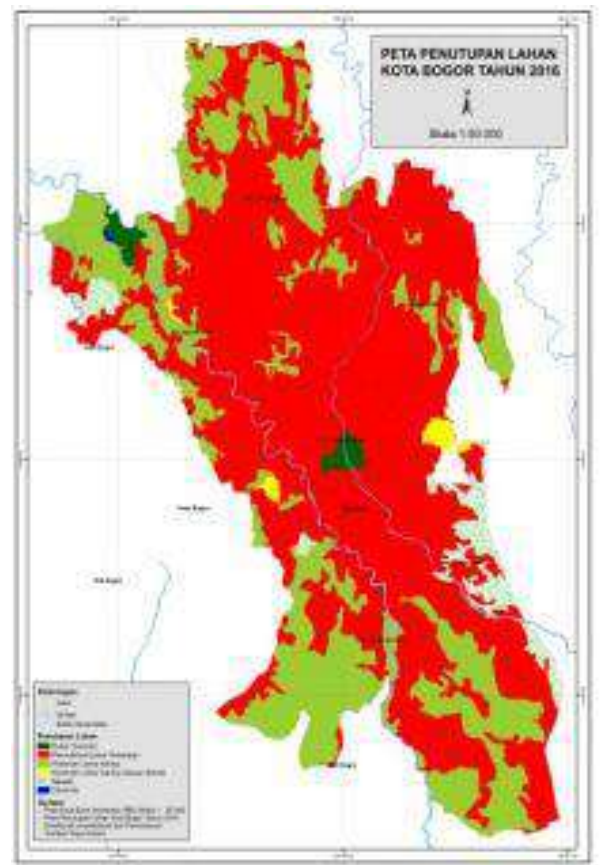

(c)

Gambar 2. Peta Penutupan Lahan Kota Bogor Tahun 1996 (a), Tahun 2006 (b) dan Tahun 2016 (c)

\subsection{Faktor yang Mempengaruhi Perubahan Penutupan Lahan}

\subsubsection{Peningkatan Jumlah Penduduk}

Kebutuhan lahan akan meningkat dengan meningkatnya jumlah penduduk. Peningkatan jumlah penduduk dapat disebabkan oleh faktor kelahiran dan urbanisasi. Banyaknya penduduk pendatang (urbanisasi) dan tingkat kelahiran yang tinggi di Kota Bogor memerlukan adanya perluasan tempat tinggal (Tabel2). Pada tabel 2 terlihat bahwa untuk kecamatan Bogor Utara, Bogor Barat dan Tanah Sareal terjadi peningkatan jumlah penduduk yang signifikan, hal ini kemungkinan terjadi karena banyaknya penduduk yang pindah dari Jakarta disebabkan seringnya terjadi banjir di Kota Jakarta. "Banjir besar terjadi di Jakarta pada tahun 2007 dimana hampir 60\% wilayah DKI Jakarta terendam banjir dengan kedalaman mencapai hingga 5 meter di beberapa titik lokasi banjir" [7]. "Tejadinya peningkatan jumlah penduduk menyebabkan terjadinya peningkatan permintaan akan perumahan sehingga lahan hijau akan semakin sedikit, sementara itu kota Bogor dilalui oleh sungai Ciliwung yang merupakan penyumbang terbesar terjadinya banjir di Jakarta, selain tingginya curah hujan di Kota Bogor yang mencapai 3500-4000 mm/tahun dan terjadinya perubahan guna lahan di kawasan puncak menambah tinggi laju limpasan permukaan "[8]. Tingginya kenaikan jumlah penduduk Bogor Utara, Bogor Barat dan Tanah Sareal adalah dikarenakan akses transportasi yang mudah ke Jakarta (Gambar 3). "Pembangunan tol lingkar luar (Bogor Outer Ring Road/BORR) yang pemasangan tiang pancangnya dilakukan pada 23 November 2005 dan peresmian pembangunan konstruksi dilaksanakan pada 14 Maret 2008, Jalan Tol Lingkar Luar Bogor diresmikan pengoperasiannya oleh Menteri Pekerjaan Umum Republik Indonesia, Djoko Kirmanto, pada 23 November 2009" [9]. 
Tabel 2. Data Kependudukan Kota Bogor Tahun 1996, 2006 dan 2016

\begin{tabular}{|c|c|c|c|c|c|c|}
\hline \multirow[t]{2}{*}{ No. } & \multirow[t]{2}{*}{ Kecamatan } & \multicolumn{3}{|c|}{ Jumlah Penduduk (Jiwa) } & \multicolumn{2}{|c|}{ Pertambahan Penduduk (Jiwa) } \\
\hline & & 1996 & 2006 & 2016 & $1996-2006$ & $2006-2016$ \\
\hline 1. & Bogor Selatan & 131.756 & 170.909 & 196.768 & 39.153 & 25.859 \\
\hline 2. & Bogor Timur & 66.976 & 89.237 & 103.389 & 22.261 & 14.152 \\
\hline 3. & Bogor Utara & 101.436 & 153.843 & 189.494 & 52.407 & 35.651 \\
\hline 4. & Bogor Tengah & 103.973 & 106.075 & 104.439 & 2.102 & 364 \\
\hline 5. & Bogor Barat & 150.008 & 195.808 & 232.634 & 45.800 & 36.826 \\
\hline \multirow[t]{2}{*}{6.} & Tanah Sareal & 119.651 & 163.226 & 221.198 & 43.575 & 57.972 \\
\hline & Jumlah & 673.800 & 879.098 & 1.047 .922 & 205.298 & 170.824 \\
\hline
\end{tabular}

Sumber : Badan Pusat Statistik Kota Bogor 1997, 2007 dan 2017

Perluasan lahan untuk tempat tinggal menyebabkan adanya perubahan guna lahan di Kota Bogor secara otomatis akan mempengaruhi penutupan lahannya. Menurut [10] "dimana faktor penting yang perlu dipertimbangkan dalam penggunaan lahan yaitu: faktor fisik lahan, faktor ekonomi, dan faktor kelembagaan. Kondisi sosial dan budaya masyarakat setempat juga perlu dipertimbangkan sebagai faktor terjadinya perubahan lahan. Dengan bertambahnya jumlah penduduk maka kebutuhan sandang dan pangan juga meningkat sehingga terjadi peningkatan permintaan terhadap hasil-hasil pertanian. Demikian pula permintaan terhadap hasil non pertanian seperti kebutuhan perumahan dan sarana prasarana wilayah. Peningkatan pertumbuhan penduduk dan peningkatan kebutuhan material cenderung menyebabkan persaingan dalam penggunaan lahan. Perubahan penggunaan lahan dalam pelaksanaan pembangunan tidak dapat dihindari. Perubahan tersebut terjadi karena dua hal, pertama adanya keperluan untuk memenuhi kebutuhan penduduk yang makin meningkat jumlahnya dan kedua berkaitan dengan meningkatnya kebutuhan tuntutan akan mutu kehidupan yang lebih baik".

\subsubsection{Keadaan Sosial Ekonomi}

"Tingkat pertumbuhan ekonomi kota Bogor tahun 2010 sampai 2014 meningkat berdasarkan data hasil sensus ekonomi tahun 2016 yang dikeluarkan oleh Badan Pusat Statistik (BPS) Kota Bogor. Peningkatan terjadi pada 17 sektor dalam Produk Domestik Regional Bruto (PDRB) Kota Bogor dalam kurun waktu tahun 2010 - 2014. Tahun 2010 PDRB Kota Bogor mencapai Rp. 17.775.588,6, keadaan ini terus meningkat setiap tahunnya hingga tahun 2014 PDRB Kota Bogor mencapai Rp. 29.102.228,9”. Keadaan yang sama juga dikatakan oleh [11] dimana kota Bogor mengalami perekembangan yang cepat dan fluktuatif, dari nilai PDRB terlihat bahwa terjadi pertumubuhan sejak 2000-2005 sebesar 12,05\%, berdasar pada data terbaru PDRB Bogor mencapai Rp. 4.051.723.000. Kota Bogor yang dijadikan sebagai kota perdagangan dan jasa tentu saja sangat mempengaruhi keadaan ekonomi kota Bogor, tidak hanya untuk pendapatan daerah saja, akan tetapi untuk masyarakatnya juga. Perkembangan sektor perdagangan dan jasa dapat dilihat dari terbangunnya pusat-pusat perbelanjaan, perhotelan, pasar, toko, warung/kios, bank dan koperasi. Meskipun pembangunan ini berdampak positif bagi keadaan sosial ekonomi, akan tetapi berdampak negatif untuk keadaan penutupan lahannya. 


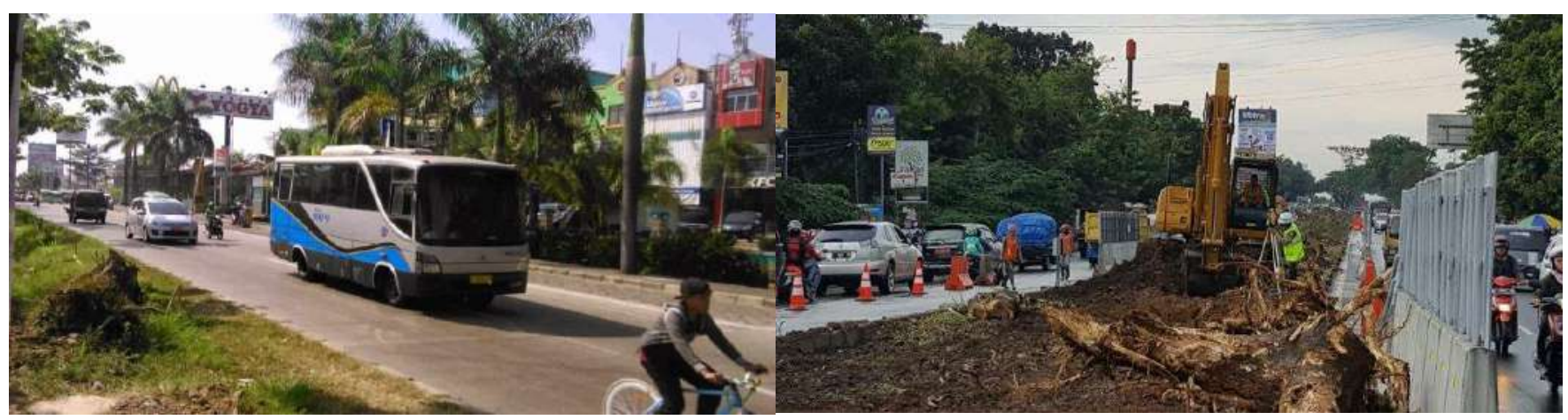

(A)

(B)

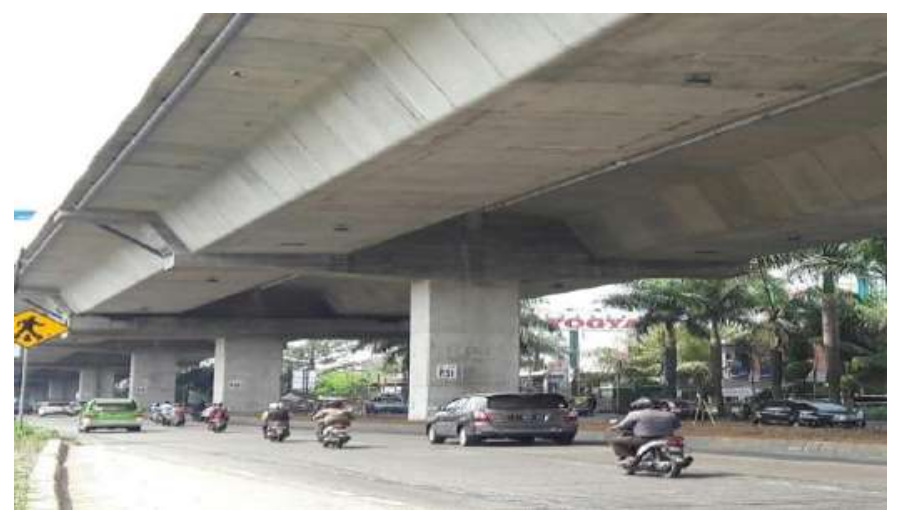

(C)

Gambar 3. Sebelum Dilakukan Pembangunan Tol BORR (A), Proses Pembangunan Tol BORR (B), Kondisi tol BORR (C)

\subsubsection{Arah Kebijakan Pemerintah Daerah}

Menurut [11] salah satu faktor yang mempengaruhi perubahan Kota Bogor adalah kebijakan pemerintah yang berkuasa pada saat itu. Penataan ruang dan wilayah tentunya akan dipengaruhi oleh kebijakan pemerintah yang berkuasa saat itu. Selain itu, kebijakan tersebut berpengaruh pada visi kota pada masing-masing penguasaan pemerintah, yang menentukan arah perekembangan kota Bogor dan wajah kota Bogor itu sendiri. "Berdasarkan Peraturan Daerah Kota Bogor Nomor 8 Tahun 2011 tentang Rencana Tata Ruang Wilayah Kota Bogor Tahun 20112031, Kebijakan dan strategi penataan ruang dilakukan melalui : 1. Kebijakan dan strategi pengembangan struktur ruang; 2. Kebijakan dan strategi pengembangan pola ruang; dan 3. Kebijakan dan strategi pengembangan kawasan strategis". Kebijakan yang sangat mempengaruhi perubahan penutupan lahan adalah pengembangan struktur ruang, karena banyak pembangunan yang dapat merubah struktur lahan bervegetasi menjadi lahan terbangun. Sebagai salah satu contoh dari arahan kebijakan pemerintah Kota Bogor dalam meningkatkan aksesibilitas dan keterkaitan antar pusat kegiatan adalah pembanguan tol lingkar luar Bogor (BORR). Pembukaan aksesibilitas memberi dampak terhadap munculnya pembangunan permukiman seperti apartemen Bogor Valley, Bogor Icon dan pusat perniagaan seperti Ramayana Dept. Store, Lotte Mart, Giant Yasmin dan Hypermart yang sangat dekat aksesnya ke pembangunan tol tersebut. Menurut [12] terjadi penebangan pohon pada saat dilakukannya pembangunan jalan tol lingkar luar Bogor yang jumlahnya sampai ratusan pohon, dimana pohon-pohon tersebut dapat menahan lajunya air hujan dan mempertahankan iklim mikro di Kota Bogor.

\section{Kesimpulan}

Klasifikasi kelas penutupan lahan kota Bogor adalah hutan tanaman, lahan terbuka, pelabuhan/bandara, permukiman/lahan terbangun, pertanian lahan kering, pertanian lahan kering campur semak, sawah, perkebunan, dan 
tubuh air. Tahun 1996 penutupan lahan masih di dominasi oleh vegetasi, semak dan belukar. Perubahan penutupan lahan terjadi paling besar pada kelas permukiman/lahan terbangun dengan luas sebesar 6.683 Ha di Tahun 2006 dan 7.532 Ha di Tahun 2016.

Perubahan tutupan lahan Kota Bogor, faktor utama yang mempengaruhinya adalah pertumbuhan penduduk, keadaan sosial ekonomi, arah kebijakan pemerintah daerah.

\section{Ucapan Terima Kasih}

Ucapan terimakasih pada Kementerian Lingkungan Hidup dan Kehutanan khususnya bagian Planologi Kehutanan dan Tata Lingkungan dan juga Badan Informasi Geospasial (BIG) yang telah membantu peneliti sehingga penelitian ini dapat diselesaikan.

\section{Referensi}

[1] A. M. Zain, "Distribution, Structure, and Function of Urban Green Spacein Southeast Asian Mega-cities with Special Reference to Jakarta Metropolitan Region (JABOTABEK)," [Disertasi].Japan(ID):The University of Tokyo, 2002.

[2] S. Hardjowigeno," Klasifikasi Tanah dan Pedogenesis". Jakarta: Akademika Pressindo, 1993.

[3] Kementerian Lingkungan Hidup dan Kehutanan direktorat jenderal Planologi Kehutanan," Pedoman Pemantauan Penutupan Lahan". Indonesia, 2015.

[4] N. I. Khusaini, "Pengaruh Perubahan Penutupan Lahan Terhadap Distribusi Suhu Permukaan," [Skripsi ]. Bogor (ID):Institut Pertanian Bogor, 2008.

[5] B. Latuamury and S. S. Totok Gunawan, "Perubahan tutupan lahan akan berdampak pada berubahnya sifatsifat hidrologi seperti koefisien aliran, debit dan karakteristik hidrograf aliran. Indikator kerusakan hutan dapat dilihat dari karakteristik hidrograf. Evaluasi respon DAS berupa hidrograf," Maj. Geogr. Indoneia, vol. 26, no. 2, pp. 98-118, 2012.

[6] P. Haryani, "Perubahan Penutupan/Penggunaan Lahan danPerubahan Garis Pantai Di DAS Cipunagara Dan Sekitarnya, di Jawa Barat," [Skripsi ]. Bogor (ID):Institut Pertanian Bogor, 2011.

[7] Wikipedia, "Banjir Jakarta 2007," Jakarta, 2007.

[8] D. J. Sudrajat, "Hubungan Perubahan Penggunaan Lahan Dengan Limpasan Air Permukaan:," Perenc. Wil. dan Kota, vol. 16, no. 3, pp. 44-56, 2009.

[9] wikipedia, "Jalan Tol Lingkar Luar Bogor," 2018.

[10] R. Barlowe," Land Resources Economic", Third Edit. New Jersey: Prentice Hall Inc. Englewood cliffs, 1978.

[11] E. Irianti, "Perubahan penggunaan, penutupan lahan, dan ruang terbuka hijau kota bogor tahun 1905-2005," [Skripsi ]. Bogor (ID):Institut Pertanian Bogor, 2008.

[12] Ilham Kusmayadi, "Ratusan Pohon Ditebang Selama Pembangunan Jalan Tol Lingkar Bogor," Merdeka.com, Bogor, 2017. 